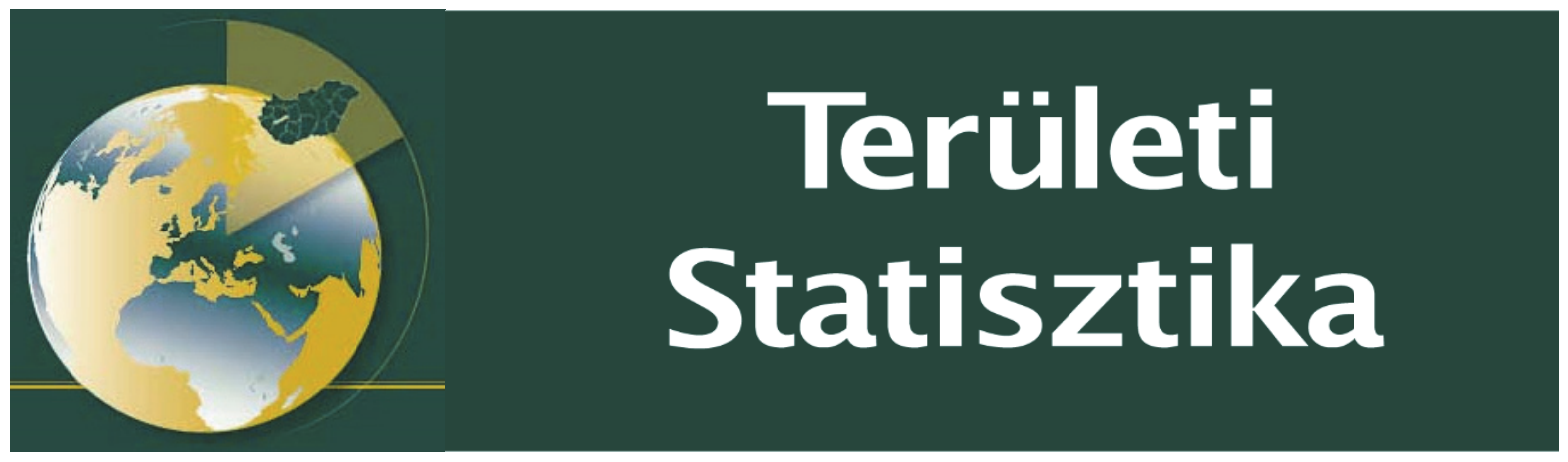

Közzététel: 2021. január 19.

A tanulmány címe:

A távolság és az iWiW közösségi oldal kapcsolathálózatának összefüggései a magyarországi belföldi vándorlással

Szerzők:

Németh Brigitta - Lörincz Lász̨ló

https://doi.org/10.15196/TS610102

Az alábbi feltételek érvényesek minden, a Központi Statisztikai Hivatal (a továbbiakban: KSH) Területi Statisztika c. folyóiratában (a továbbiakban: Folyóitat) megjelenó tanulmányra. Felhasználó a tanulmány, vagy annak részei felhasználásával egyidejüleg tudomásul veszi a jelen dokumentumban foglalt felhasználási feltételeket, és azokat magára nézve kötelezónek fogadja el. Tudomásul veszi, hogy a jelen feltételek megszegéséböl eredö valamennyi kárért felelösséggel tartozik.

1) A jogszabályi tartalom kivételével a tanulmányok a szerzői jogról szóló 1999. évi LXXVI. törvény (Szjt.) szerint szerzői műnek minősülnek. A szerzői jog jogosultja a KSH.

2) A KSH földrajzi és időbeli korlátozás nélküli, nem kizárólagos, nem átadható, térítésmentes felhasználási jogot biztosít a Felhasználó részére a tanulmány vonatkozásában.

3) A felhasználási jog keretében a Felhasználó jogosult a tanulmány:

a) oktatási és kutatási célú felhasználására (nyilvánosságra hozatalára és továbbítására a

4. pontban foglalt kivétellel) a Folyóirat és a szerző(k) feltüntetésével;

b) tartalmáról összefoglaló készítésére az írott és az elektronikus médiában a Folyóirat

és a szerző(k) feltüntetésével;

c) részletének idézésére - az átvevő mú jellege és célja által indokolt terjedelemben és az eredetihez híven - a forrás, valamint az ott megjelölt szerző(k) megnevezésével.

4) A Felhasználó nem jogosult a tanulmány továbbértékesítésére, haszonszerzési célú felhasználására. Ez a korlátozás nem érinti a tanulmány felhasználásával elóállított, de az Szit. szerint önálló szerzői műnek minősülő mú ilyen célú felhasználását.

5) A tanulmány átdolgozása, újra publikálása tilos.

6) A 3. a)-c.) pontban foglaltak alapján a Folyóiratot és a szerző(ke)t az alábbiak szerint kell feltüntetni:

„Forrás: Területi Statisztika c. folyóirat 61. évfolyam 1. sqámában megjelent, Németh Brigitta - Lörincz László által irt, A távolság és az iWiW közösségi oldal kapcsolathálózatának összefüggései a magyarországi belföldi vándorlással c. tanulmány”

7) A Folyóiratban megjelenő tanulmányok kutatói véleményeket tükröznek, amelyek nem esnek szükségképpen egybe a KSH, vagy a szerzők által képviselt intézmények hivatalos álláspontjával. 


\title{
A távolság és az iWiW közösségi oldal kapcsolathálózatának összefüggései a magyarországi belföldi vándorlással *
}

\section{Correlations between distance and the personal connections on the iWiW social network with internal migration in Hungary}

\author{
Németh, Brigitta \\ Közgazdaság- és Regionális \\ Tudományi Kutatóközpont, \\ Közgazdaságtudományi Intézet \\ E-mail: nemeth.brigitta@krtk.hu \\ A kutatás a kapcsolathálóknak a magyaror- \\ szági belföldi vándorlásban játszott szerepével \\ foglalkozik. A szerzők a letelepedés helyének \\ kiválasztását befolyásoló hatásokat vizsgálják, \\ elsősorban az online kapcsolatokat, valamint \\ a települések közötti távolság és a kapcsolat- \\ háló kölcsönhatását. Az elméleti modellben a \\ Lörincz, László \\ Budapesti Corvinus Egyetem, \\ „Networks, Technology and \\ Innovations" Kutatócsoport \\ E-mail: \\ laszlo.lorincz@uni-corvinus.hu \\ települések infrastrukturális és gazdasági jel- \\ lemzői mellett a kapcsolathálózati tényezők \\ további push- és pull-faktorokként jelennek \\ meg, és emellett befolyásolják a távolság hatá- \\ sát is. A települések jellemzőiről és a vándor- \\ lásról adminisztratív adatok, az online kapcso- \\ latokról pedig az iWiW közösségi oldal adatai \\ álltak rendelkezésre az elemzéshez. Az ered- \\ mények alapján a települések kiválasztása po- \\ zitív és szignifikáns összefüggésben van az \\ online közösségi hálón fenntartott kapcsola- \\ Kulcsszavak: \\ tok számával és irányával. A vándorlások \\ belföldi migráció, \\ nagy része kis és közepes távolságra irányul, \\ kapcsolatháló, \\ ezen belül pedig azokat a céltelepüléseket ré- \\ iWiW, \\ szesítik előnyben a vándorlók, amelyeket sû- \\ információs hipotézis, \\ rúbb kapcsolatháló köt össze a küldő telepü- \\ vándorlási távolság \\ lésükkel.
}

* A Magyar Statisztikai Társaság Területi Statisztikai Szakosztálya és az MTA IX: osztály Regionális Tudományok Bizottsága Kutatás-módszertani Albizottsága által rendezett, „A távolság halála? $-A$ távolság viągálatának kiülönbözố megközelitése a területi kutatásokban” címú konferencián 2020. március 5-én tartott előadás szerkesztett változata.

Területi Statisztika, 202 1, 61(1): 26-47; DOI: 10.15196/TS610102 
Keywords:

Hungarian internal migration, social networks,

iWiW - online social network site, information hypothesis, distance of migration
Our research focuses on the role of social networks in Hungarian internal migration. We examine the influence of online social networks and that of the distance between settlements on the choice of destination. The network effects appear in our model as additional push and pull factors for the individual beside the infrastructural and economic characteristics of the municipalities, and we expect them to modify the impact of distance on migration. We analyzed administrative data on migration (source and destination matrix) and settlement characteristics. The effect of social networks has been measured by the user-user connections between two settlements on iWiW social network site. Our results, based on fixed-effect poisson regression models, show that the choice of destination is associated with the network effects. Most of the relocations take place within short and medium distances, and within this, migrants prefer destinations that are more densely connected to their place of origin on the social network site.

Beküldve: 2020. június 28.

Elfogadva: 2020. október 15.

\section{Bevezetés}

A vándorlás a várható haszon mellett számos költséggel és kockázattal is jár, továbbá a társas kapcsolathálók és a rajtuk keresztül beszerezhető információ pedig az egyik legfontosabb eszköz a kockázat, valamint a bizonytalanság csökkentésére (DaVanzo 1981). Az egyén számára így a rokonok és barátok jelenléte fontos a lakóhellyel kapcsolatos döntések meghozatalakor.

A társadalmi kapcsolathálók hatása megfigyelhetô a letelepedés helyének kiválasztásában. A push- és pull-elmélet (Ravenstein 1889) szerint míg a jelenlegi lakóhely kedvezôtlen körülményei az elvándorlást, addig a más településeken elérhető lehetőségek pedig az odavándorlást ösztönzik. Úgy véljük, hogy ezek közé a vonzó és taszító tényezők közé tartozik a családtagok, az ismerősök jelenléte is. A klasszikus elmélet szerint a települések vonzó és taszító tulajdonságai mellett a távolság

Területi Statisztika, 2021, 61(1): 26-47; DOI: 10.15196/TS610102 
határozza meg a vándorlás volumenét. A vándorlásra a pszichés költségek és a távolság növekedésével csökkenő mennyiségben elérhető információ révén hat a távolság, és e két tényező hatását az online kapcsolathálók - véleményünk szerint módosíthatják.

A hálózatok szerepének vizsgálata során a szükséges adatok összegyüjtése az egyik legnagyobb feladat; mivel a vándorlásra és a társas kapcsolathálóra vonatkozó adatokra is szükség van. Tanulmányunkban adminisztratív adatokat vizsgálunk a települések közötti vándorlásról, majd ezeket összekötjük az iWiW közösségi oldal kapcsolathálózati adatbázisával. Ellentétben a gyakran csak egy kisebb földrajzi egységre vonatkozó survey adatokkal, tanulmányunkban lehetőségünk van az összes magyarországi vándorlás elemzésére. Ezeket az adatbázisokat településszinten kapcsoljuk egymáshoz. A települések különböző jellegzetességeirôl szintén részletes adatbázis áll rendelkezésre, így összesen közel 10 millió településpárt vizsgálhatunk.

E kutatásunkban építünk az e témában megjelent korábbi tanulmányunkra is (Németh-Lőrincz 2019), amelyben az online kapcsolathálóknak az elvándorlásra és a letelepedés helyének kiválasztására gyakorolt hatását elemezzük. Jelen vizsgálatunkban a letelepedés helyének kiválasztására összpontosítunk az online kapcsolatok és a távolság összefüggésében. Elsőként a kifelé irányuló kapcsolatok eloszlásának hatását vizsgáljuk, vagyis azt, hogy a két település közötti sűrűbb kapcsolatháló népszerúbbé teszi-e az adott céltelepülést a többinél? Másodikként pedig azt, hogy a közösségi oldalon fenntartott kapcsolatok hogyan befolyásolják a földrajzi távolság hatását a letelepedés helyének kiválasztásában?

Az utóbbi időben több kutatás is foglalkozott a digitális kapcsolathálózatok és a vándorlás összefüggéseivel. Blumenstock és szerzőtársai (2019) például a mobiltelefonkapcsolat-hálózati adatok mintázatait vizsgálták 30 földrajzi körzet között Ruandában, arra koncentrálva, hogy a letelepedési lehetőségek népszerúségét az ott élő ismerősök mennyire befolyásolják. Büchel és szerzőtársai (2020) a svájci belföldi vándorlást elemezték szintén mobiltelefonkapcsolat-hálózati adatok segítségével. Az elvándorlásra és a letelepedés helyének kiválasztására vonatkozó döntést is vizsgálták, a letelepedési hely kiválasztásának modellezésekor pedig figyelembe vették a kapcsolatok jellegét is. Fontos különbség, hogy míg az említett kutatások egyéni szinten vizsgálódnak, addig mi településszinten.

A belföldi vándorlás hiánya gyakran felelős a munkaerőpiaci területi egyenlötlenségekért (Alpek et al. 2018, Kóti 2018). Magyarországon a rendszerváltás után megnőttek a gazdasági egyenlőtlenségek a különböző régiók között, ami aztán magas munkanélküliséggel járt az észak-keleti megyékben és a kisebb, periférián található településeken (Fazekas 2002, Tagai et al. 2018, Novotný-Pregi 2018). 2017-től viszont a fejlettebb nyugati országrészen a képzett és képzetlen munkaerő hiányáról, valamint termelésikapacitás-növelési igényrôl számoltak be a munkáltatók (Hajdu et al. 2018). Ezt alátámasztották az általunk 2017-ben, a Dunántúlon folytatott interjúk is. A munkaerőhiány kérdése emellett rendszeresen felmerült a nyilvánosság részéről 
is (Tóth-Nyírő 2018). Az empirikus kutatások azt mutatják, hogy a munkaerőpiaci jellemzők nem közvetlenül hatottak a vándorlásra a rendszerváltás után (Kertesi 1997), azonban a munkanélküliség és a bérkülönbségek befolyásolták azt (CseresGergely 2005).

\section{Kapcsolódó elméletek}

A vándorlással több tudományterület is részletesen foglalkozik, ebben a fejezetben csak a témához szorosabban kapcsolódó elméleteket mutatjuk be. A migrációs áramlatok egyik első modelljét, a push- és pull-elméletet Ravenstein (1889) fogalmazta meg. Fố megállapítása, hogy míg a potenciális elvándorlókat a céltelepülésen elérhető lehetőségek bevándorlásra sarkallják, addig a korábbi lakóhely kedvezőtlen körülményei elvándorlásra ösztönzik. A migráció volumenét és irányát e két tényező mellett a vándorlás távolsága határozza meg, és Ravenstein kutatása szerint a vándorlások jelentős része viszonylag rövid távolságra irányul. Dorigo és Tobler (1983) később ezt úgy fogalmazzák meg, hogy push-faktorok azok az élethelyzetek, amelyek miatt az egyén elégedetlen az aktuális lakóhelyével, a pull-faktorok pedig azok a tulajdonságai a céltelepülésnek, amelyek miatt az vonzónak tűnik. A két település közötti távolság megadható kilométerben, útidőben (személygépkocsival, közúton megtett út percben mért ideje), útiköltségben, társadalmi távolságban vagy munkalehetőségekben is.

\section{A kapcsolathálók szerepe a letelepedés helyének kiválasztásában}

Az emberi tôke elmélete szerint a migráció egy befektetés, várható költségekkel és hasznokkal (Sjaastad 1962). A letelepedési hely kiválasztásában érvényesülő hálózati hatások kutatása például gyakran vizsgálja az információba való befektetés folyamatát. Az információgyűjtés csökkenti a vándorlásbefektetés bizonytalanságát; és a kapcsolathálózatok éppen ilyen jellegú információt biztosítanak. Ebből következik, hogy a potenciális vándorló a könnyen hozzáférhető információkat fogja elsősorban összegyújteni, és ezek pedig általában azokról a településekről állnak rendelkezésére, ahol rokonok, barátok és ismerôsök élnek (DaVanzo 1981, Kincses-Bálint 2016a, b, Bálint et. al. 2017). Megfigyelték azt is, hogy gyakran a rokonok a forrásai a tájékozódáshoz szükséges vagy a lakhatással, a munkaerőpiaccal kapcsolatos tudásnak (Blumberg-Bell 1958, Choldin 1973, Banerjee 1983).

A rokonok és barátok jelenléte nemcsak a költözés során, de hosszú távon is hasznos. A családtagok segítséget, pénzügyi, érzelmi támogatást és társaságot nyújtanak egymásnak (Wellman-Wortley 1990). Ezek a tényezők pedig befolyásolják az új lakóhely kiválasztását, különösen olyan családok esetében, akik jelentős mértékben támaszkodnak tagjaikra, ha valamilyen szolgáltatásra van szükségük (Stokenberga 2019).

Területi Statisztika, 2021, 61(1): 26-47; DOI: 10.15196/TS610102 
A kapcsolathálózatok említett két hatása nem pénzügyi elemként értelmezhető a migráció push- és pull-modelljében. Az első az „információs hipotézis”, a második pedig ,a rokonság vonzásának hipotézise” (Ritchey 1976).

A kapcsolathálók további szerepe, hogy segítenek a letelepedőknek megfelelő munkát találni. Például, ha egy jelentkezőnek korábbi munkatársai már a vállalatnál dolgoznak, az növeli az általa kialkudható bért (Hensvik et al. 2016, Glitz-Vejlin 2018, Boza-Ilyés 2018), valamint a felvétel esélyét is (Saygin et al. 2014). Más típusú ismeretségi hálók, mint például a származási viszonyok (Kramarz et al. 2014), a katonai szolgálatból való ismeretségek (Laschever 2013), vagy egy tömbházból való ismeretség (Bayer et al. 2008) szintén befolyásolják a foglalkoztatás esélyét és a várható béreket.

\section{Hálózatok és láncmigráció}

Az új lakóhelyen való letelepedés nem jelenti feltétlenül a korábbi kapcsolatok megszakítását. Az elköltözők gyakran látogatnak haza a családhoz a házasságkötés és a gyermekek megszületése után is (Litvak 1960, Schwarzweller 1964), így új kapcsolatokat alakítanak ki a korábbi és az új lakóközösség között. Minden vándorló csökkenti a migráció költségét a rokonai és a barátai számára (Massey et al. 1993). Ez a mechanizmus vezet az ún. láncmigrációhoz.

Ahogy a korábbi elvándorlók kapcsolathálózatot alakítanak ki a korábbi és jelenlegi lakóhelyük között, ezzel egy önmagát erősítő folyamat indulhat el, amelynek során a települések közötti vándorlás további kapcsolatokat hoz létre, amelyek azután további vándorlásokhoz vezetnek. Ebből azt a következtetést vonhatjuk le, hogy a korábbi vándorlás jó indikátora a hálózati kapcsolatoknak. Carrington és szerzőtársai (1996) kutatásukban arra jutottak, hogy például az Egyesült Államokban a XX. század első felében a feketék déli államokból az északiakba való vándorlása (great migration) egy endogén költségeket feltételező modellel írható le, amiben a megelőző vándorlások csökkentik a következő vándorlók költségeit. Deléchat (2001) szerint is a családban vagy a származási közösségben előforduló migrációs tapasztalat hatással van az egyén migrációs döntésére. Bauer és szerzőtársai (2002) Mexikóból az Egyesült Államokba bevándorlók vizsgálatából megállapították, hogy a letelepedők aránya a település népességén belül összefüggést mutat azzal, hogy mekkora valószínúséggel választják további mexikói bevándorlók az adott települést letelepedésre.

\section{Online közösségi oldalak és migráció}

A jelenleg múködő közösségi oldalak (Twitter, Facebook) napi tartalommegosztásra épülnek, azonban a korábbiak (például az iWiW) jóval profilcentrikusabbak voltak. A központi funkció a profilok információval való megtöltése volt (mint egy digitális, képes telefonkönyv) és a kapcsolatfelvétel lehetőségének biztosítása (Ellison-Boyd 2013). Ezek a funkciók megkönnyítették a múködő kapcsolatok megtartását és a korábbi ismeretségek felélesztését. 
A közösségi oldalak ilyen szolgáltatásai a vándorlók számára talán még inkább felértékelődnek. Az internetes kapcsolattartás segítségével az elköltözők kisebb mértékben veszítik el korábbi kapcsolataikat (Hampton-Wellman 2001), így hozzájárulnak a származási közösséghez való tartozás érzetének megtartásához (DekkerEngbersen 2014), és ennek a közösségnek a támogatása is elérhető ezeken a felületeken (Ye 2006, Chen-Choi 2011).

Az említett oldalak segítik a kapcsolatok ápolását, újak kialakítását és a korábbiak újrafelvételét. Az új vagy újjáélesztett ismeretségek az információk és a segítségnyújtás lehetőségeit is magukban rejtik a költözés folyamatával, az új településsel, valamint a lakhatási és munkalehetőségekkel kapcsolatban, ezen felül pedig megkönnyítik az új lakó beilleszkedését a helyi közösségbe (Hiller-Franz 2004, DekkerEngbersen 2014). Az online kapcsolathálók hatása tehát nagymértékben hasonlít a természetes, nem online kapcsolathálókéhoz a vándorlás szempontjából; így a közösségi oldalon jelen lévő kapcsolathálózatok vándorlással kapcsolatos befolyásának vizsgálatában hasonló hatást várunk, mint amit a közösségi oldalak előtti időkben várnánk egy kapcsolathálózattól.

A fizikai közelségnek ugyanakkor meghatározó szerepe van a virtuális társadalmi kapcsolatok formálásában és fenntartásában is, azonban a távolságtól való függés gyengébb az online közösségi hálózatban, mint a korábbi, a telefonon történő kommunikációs hálózatokban (Lengyel et al. 2016). A távolság akadályozó hatása tehát kevésbé érvényesül a közösségi oldalak előretörésével (mivel azok csökkentik a kommunikációs költségeket), de nem szüntetik meg teljesen.

\section{A távolság szerepe}

A vándorlásra két tényezőn keresztül hat a távolság: az egyik a pszichés költségek, a másik a két település közötti távolság növekedésével csökkenő mértékben elérhetô információ. Schwartz (1973) szerint a vándorlás távolságérzékenysége elsősorban információs probléma. Coombs (1978) pedig azt vizsgálta, hogy a lehetőségekkel kapcsolatos információk és ezek eloszlása a társadalmi kapcsolathálókban hogyan befolyásolja a vándorlás és a távolság összefüggését. Kutatásában megerősíti az információs hálózatok hipotézisét, mely szerint a céltelepülésen lévő kapcsolatok befolyásolják a távolság és a vándorlás alapvető összefüggését. Mulder és van der Meer (2009) kutatása alapján kis (<40 kilométer) távolság esetén még jól múködik a családtagok közötti segítségnyújtás, ez esetben tehát kevésbé szakadnak meg az eredeti kapcsolatok. Ermisch és Mulder (2019) a szülőktől való távolság és a nagyobb távolságra (legalább 40 kilométer) vándorlás közötti kapcsolatot elemzik brit belföldi paneladatokon. Míg a szülőktől távoli lakóhely növeli a nagy távolságú költözések valószínűségét, addig a szülőkkel való heti rendszerességú találkozás és a szomszédokkal való kapcsolat csökkenti annak valószínűségét. Kutatásuk alapján a rokonság vonzásának hipotézise érvényes a távolság tekintetében is.

Területi Statisztika, 2021, 61(1): 26-47; DOI: 10.15196/TS610102 
A vándorlás - definíciója szerint - egymástól elkülönülő térbeli egységek közötti mozgást jelent, aminek az egyik legfontosabb jellemzője a távolság. Anyagi költsége és pszichés terhei pedig (eltávolodás a családtagoktól, barátoktól vagy a személyes kapcsolatok megritkulása) a távolsággal növekednek Magyarországon is, ennek megfelelóen a települések közötti mozgás sokkal intenzívebb, mint a megyék vagy régiók közötti vándorlás. Ezer lakosra 19 más településre történő állandó lakóhely-változtatás jut évente, másik megyébe 9-10, másik régióba csupán 6 (Bálint-Gödri 2015).

\section{Hipotézisek}

Azt feltételezzük, hogy ezek az egyéni szinten ható mechanizmusok megragadhatóak a közösség szintjén is. A rokonság vonzásának hipotézise szerint a rokonok és barátok fontos forrásai a kisebb-nagyobb segítségeknek és társas támogatásoknak. Ha az egyéneknek több online kapcsolata van más településen élókkel, az növelheti településeik vonzerejét, emellett információs költségeik is kisebbek.

Az információ és a kapcsolatokban rejlő előnyök adott településekhez kötődnek. Ha a lakóknak több kapcsolatuk van egy adott településsel, akkor valószínúbb, hogy elvándorlás esetén ezt a céltelepülést fogják választani, mivel kisebb az információs költség és kisebbek a kockázatok is, mint más település választása esetén. Tehát az információs hipotézis és a rokonság vonzásának hipotézise alapján is azt feltételezzük, hogy:

\section{H1. Egy településról elvándorolva többen telepszenek le olyan településen, amellyel a megelözó lakóhelyüknek több a kapcsolata a közösségi oldalon.}

Mivel egyéni szinten ható mechanizmusokból következtetünk közösségi szinten megjelenő kimenetelre, így fontos annak tisztázása, hogy ezek az egyéni szintủ hatások hogyan adódhatnak össze. Álláspontunk szerint a rokonok és barátok jelenléte egy településen vonzó tulajdonság az egyének számára. Mivel ez a hatás monoton (nem tudunk róla, hogy lenne olyan maximuma, ahonnan kezdve a jelenlétük már nem hasznos), úgy véljük, hogy ez a hatás hasonló közösségi szinten is.

A két település közötti távolság növekedésével csökken annak a valószínúsége, hogy a vándorló a távoli települést választaná a letelepedésre; elsősorban a költségek és a bizonytalanság növekedése miatt. Mi van azonban akkor, ha vannak olyan ismerősei a közösségi oldalon keresztül azon a távoli településen, akikre támaszkodhat és akik információval szolgálhatnak? Úgy véljük, hogy:

\section{H2. Több online kapcsolat esetén többen választanak adott települést, még a nagyobb távolság ellenére is.}

Elemzésünkben figyelembe kell vennünk a migrációt alakító nem hálózati jellegú hatásokat is; hogyha ezek összefüggenek a vizsgált mechanizmusokkal, és ha nem 
kontrollálunk ezekre az elemzésben, akkor e hatások torzítanák az eredményeinket. Az elérhető fogyasztási lehetőségek például befolyásolják a lakóhellyel való elégedettséget, és ezen keresztül az elvándorlást is (Speare 1974). Az ilyen befolyásoló erejủ tulajdonságok lehetnek a laksűrűség és a különböző piaci és közszolgáltatások, mint az üzletek és éttermek, az iskolai oktatás színvonala, vagy az egészségügyi szolgáltatások, a gyermekgondozási intézmények és a közbiztonság (Nechyba-Strauss 1998, Kim et al. 2005, Špačková et al. 2016, Szabó 2019).

\section{Adatok és módszertan}

\section{Adatok}

Elemzésünkben négy adatbázisból dolgoztunk. Az első adatforrás az iWiW közösségi oldal kapcsolathálózata. Az oldalt 2002-ben magánszemélyek alapították, majd 2006-ban a Magyar Telekom felvásárolta. Népszerúsége csúcsán, 2009-ben több mint 3 millió felhasználót szolgált ki az akkori 5 millió magyar internethasználóból. A Facebook megjelenése után, 2010-től az iWiW veszített népszerúségéből, és 2014ben a szolgáltató lekapcsolta az oldalt. Összes felhasználójának adatait (belépési dátum, nem, életkor, lakóhely) és a közöttük lévő kapcsolatokat a szolgáltató anonim módon archiválta, melyekhez az OTKA K-129124 „Egyenlőtlenségek és egyensúlytalanságok a nagy hálózatokban” kutatási projekt keretében fértünk hozzá.

Egy közösségi oldal teljes adatbázisa rengeteg információt tartalmaz, de belőlük a teljes társadalomra levontható következtetésekkel óvatosan kell bánni. Egy ilyen adatbázis szinte mindig hiányos vagy hibás, a mintavételen alapuló reprezentativitás még a legjobb minőségű adatbázis esetében sem garantált (Ságvári 2019). Az általunk elemzett kapcsolatháló, az iWiW 2013. évi, tehát a legkésőbbi állapotát tükrözi, melyet azért választottunk, hogy a lehető legkisebb mértékben érvényesüljön a szelekciós hatás (a kistelepülésen élők jellemzően később regisztráltak az iWiW-re, mint a nagyvárosiak). Emiatt felmerül viszont az a kérdés, hogy a regisztrált felhasználók aktívak voltak-e már ebben az idôszakban. Számolni kell az információk elavulásával is, tehát azzal, hogy nem minden felhasználó frissítette az adatait (például lakóhelyét). Az iWiW-felhasználók köre emellett nem reprezentatív a lakosságra nézve. A fơvárosban él a 15-60 éves népesség 16,5, a megyeszékhelyeken 17,4, a többi városban 33,9 és a falvakban 32,2\%-a. Ehhez képest az iWiW-felhasználók körében nagyobb a városban élők aránya (fơvárosé 23,6 , a megyeszékhelyeké 22,5 , a többi városoké 33,3\%) és kisebb (20,6\%) a falvakban élóké (1. táblázat).

Területi Statisztika, 2021, 61(1): 26-47; DOI: 10.15196/TS610102 


\section{A 15-60 éves népesség és iWiW-felhasználók száma, megoszlása településtípusonként, 2013}

Number and distribution of the population and iWiW users by settlement type, 2013

\begin{tabular}{|c|c|c|c|c|}
\hline Megnevezés & Főváros (N=1) & $\begin{array}{l}\text { Megyeszékhely } \\
\quad(\mathrm{N}=18)\end{array}$ & Város $(\mathrm{N}=287)$ & Falu $(\mathrm{N}=2,841)$ \\
\hline & \multicolumn{4}{|c|}{ Népesség } \\
\hline Száma, fő & 1022428 & 1080853 & 2113766 & 2003704 \\
\hline \multirow[t]{2}{*}{ Megoszlása, \% } & 16,5 & 17,4 & 33,9 & 32,2 \\
\hline & \multicolumn{4}{|c|}{ iWiW-felhasználók száma } \\
\hline Száma, fő & 727656 & 692325 & 1025684 & 635236 \\
\hline Megoszlása, \% & 23,6 & 22,5 & 33,3 & 20,6 \\
\hline
\end{tabular}

A belföldön vándorlók 44,2\%-a volt férfi és 55,8\%-a nő, illetve az iWiWfelhasználók 44,9 és 55,1\%-a. A 20-29 és 30-39 éves korcsoportok a legmobilabbak, és együtt valamivel több mint a felét (27,5 és 27,4\%) teszik ki a vándorlók 2013. évi számának. Az iWiW-felhasználók eloszlása ehhez hasonló, a legtöbben a 30-39 éves korcsoportból regisztráltak. A legidősebbek körében kevésbé elterjedt az iWiW használata, csakúgy mint a vándorlók körében (1. ábra). Ettől a korcsoporttól, vagyis a 60 év felettiektől eltekintettünk az elemzésben.

\section{A vándorlás és az iWiW-felhasználók megoszlása nemenként és korcsoportonként, 2013}

Distribution of migration and the iWiW users by age and gender, 2013

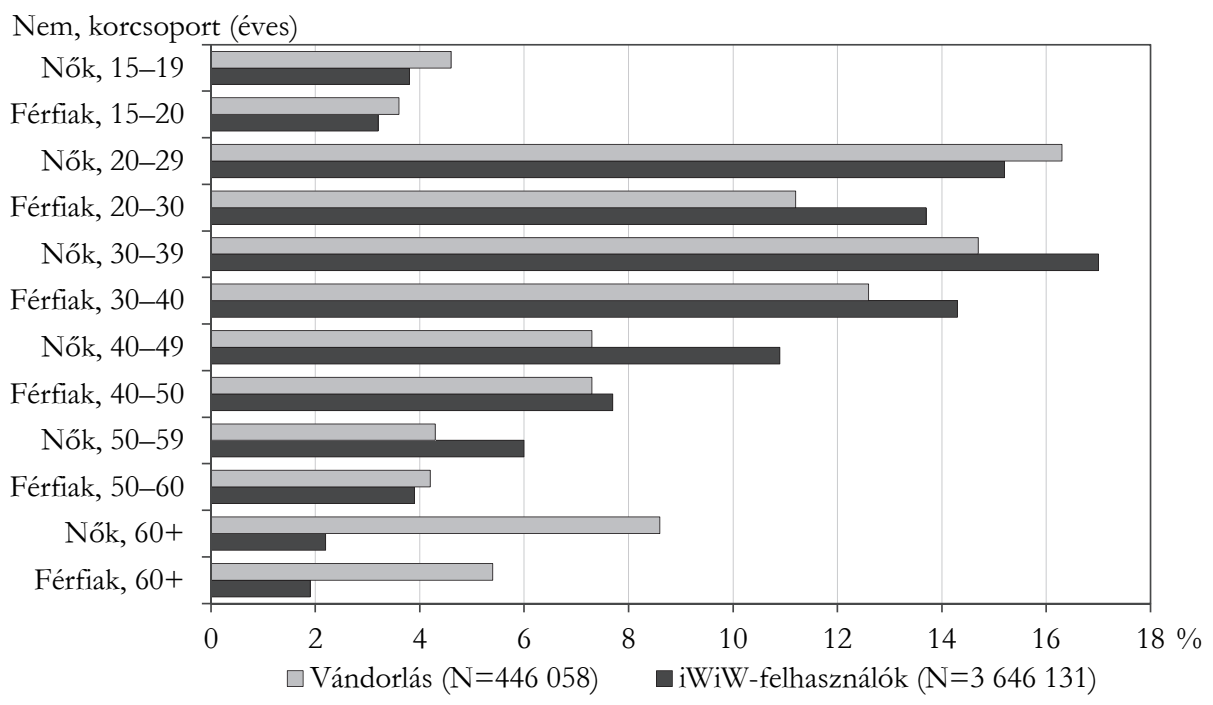


A települések közötti vándorlás adatait a második adatbázisból, a Központi Statisztikai Hivatal (KSH) 1975 és 2014 közötti belföldi vándorlásra vonatkozó adatbázisából vettük, melyhez a KSH kutatószobájában fértünk hozzá. Ebben megtaláltuk azt, hogy az új lakcímigényléseket melyik évben, melyik hónapban milyen korú, nemú, családi állapotú személyek kezdeményezték, és melyik településről melyik településre jelentkeztek át ideiglenes vagy állandó lakcímre. Az adatbázisban tehát nem azonosítható a vándorló személye, és az sem, hogy az adott vándorló ideiglenes lakcím igénylésekor például hol rendelkezik állandó lakcímmel. Emellett tény, hogy nem minden költözést jelentenek be az okmányirodákban, így a vizsgálatunkból kiesnek azok, akik hivatalos adminisztráció nélkül költöznek.

A harmadik fő adatbázis a KSH T-Star (településstatisztikai) adatbázisrendszere, amely az ország valamennyi településének információit gyüjti egybe, témacsoportonként rendszerezve. Kutatásunkhoz 22 változót választottunk ki belőle a települések infrastruktúrájának, munkaerőpiaci és gazdasági jellemzőinek leírására. Az elemzéshez ezeket a változókat főkomponens-elemzéssel 6 faktorba vontuk össze (Németh-Lőrincz 2019).

A negyedik adatbázisból, az MTA Közgazdaság- és Regionális Tudományi Kutatóközpont (KRTK) Adatbank által készített „KÖZÚT” adatbázisból vettük a települések közötti útidőt (személygépkocsival, közúton megtett út percben mért ideje), a települések közötti távolság mérésére.

\section{Változók és elemzési módszerek}

Az elemzésben a függő változó településpárra vonatkozik: a két település közötti, adott irányú vándorlás volumene (az összes lehetséges magyarországi településpárkombináció esetén a 15-60 éves 2014-ben vándorló, az ideiglenes és az állandó vándorlás megkülönböztetése nélkül). Azon települések esetében, amelyek között nem volt vándorlás, ennek értéke 0 .

A közösségi háló segítségével mért kapcsolati sűrúségnek a letelepedési hely kiválasztására gyakorolt hatásáról azt feltételeztük, hogy a két település közötti sűrủ kapcsolatháló népszerúvé teszi az adott viszonylatot az elvándorlók körében (H1). Ezt az egy felhasználóra jutó, két település között az iWiW-en fenntartott kapcsolatok számával mértük (itt szintén a 15-60 éves felhasználók adatait használva). Amelyik településpár esetén nincsen kapcsolat a felhasználók között, ott ennek az értéke szintén 0 .

Úgy véljük, hogy a távolság (útidő) növekedésével erősödik a kapcsolatháló befolyása a letelepedési hely kiválasztására (H2). Ezt interakciós változóval is mérjük; a két település között az iWiW-en fennálló kapcsolatok számát a többi településsel fenntartott kapcsolatok számához viszonyítjuk (fó magyarázó változó), majd ezt az útidôvel összeszorozzuk.

A legmagasabb egy főre jutó kapcsolat két település között 188,85 volt (a legalacsonyabb természetesen 0 , mivel nem minden településpárt köt össze lakosaik közötti online kapcsolat). A legnagyobb távolság két település között 627 percnyi autóút, a legtöbb egyirányú vándorlás két település között pedig 1363 fő volt 2013-ban.

Területi Statisztika, 2021, 61(1): 26-47; DOI: 10.15196/TS610102 
A fóbb változók leíró statisztikái, 2013

Descriptive statistics of main variables, 2013

\begin{tabular}{|c|c|c|c|c|c|}
\hline Változó & $\begin{array}{l}\text { Esetszám } \\
\text { (N) }\end{array}$ & Átlag & Szórás & Minimum & Maximum \\
\hline A településpárok közötti vándorlás & 10026722 & 0,0347 & 1,7498 & 0 & 1363 \\
\hline Távolság (útidő, perc) & 9950688 & 190 & 85 & 0 & 627 \\
\hline $\begin{array}{l}\text { A településpárok iWiW-kapcsolatainak } \\
\text { egy főre jutó száma }\end{array}$ & 6633200 & 0,0625 & 1,2346 & 0 & 188,8500 \\
\hline
\end{tabular}

Az infrastrukturális adottságok, gazdasági jellemzők, közszolgáltatások és fogyasztási lehetőségek szintén befolyásolják a vándorlást. Ezek jellemzésére korábbi kutatásunk során létrehoztunk egy komplex indikátorrendszert, amely általánosan leírja a települések olyan tulajdonságait, amelyek azt mutatják, hogy egy település mennyire lehet vonzó munkalehetőségek, közszolgáltatások, fogyasztási lehetőségek és lakhatási szempontok alapján. Ez a következő 6 faktort jelenti: városi közszolgáltatások, alapvető közszolgáltatások, helyi gazdaság, munkaerőpiac, szolgáltató jelleg, ipari jelleg (a települések jellemzőit leíró változók főkomponens-elemzésének korrelációs mátrixát lásd a Melléklet 1. táblázatában).

Az elemzésben szerepelnek a letelepedési hely további sajátosságai is, a település jellegzetességei mellett. Így a népesség, a településtípus, valamint a településpárokról az, hogy azonos megyében találhatóak-e, melyek szintén befolyásolják a vándorlás volumenét és az online kapcsolatokat is.

Az elemzés során Poisson regresszióval dolgoztunk, mivel jelentős a 0 értékek száma a függő változóban. A következő egyenletet becsüljük a Magyarországon belüli településpárokra (ij):

$$
\begin{aligned}
M_{i j, 2014}=\alpha+ & \beta_{1} M_{i j, 2013}+\beta_{2} \frac{\operatorname{conn}_{i j, 2013}}{u s e r}+\beta_{3} f_{j, 2013}+\beta_{4} \text { Type }_{j}+\beta_{5} \text { Pop }_{j, 2013}+\beta_{6} d_{i j}+\beta_{7} d_{i j}^{2} \\
& +\beta_{8} d_{i j} * \frac{\text { conn }_{i j, 2013}}{u s e r}+\beta_{9} d_{i j}^{2} * \frac{\text { conn }_{i j, 2013}}{u s e r}+\beta_{10} S C_{i j}+\gamma D_{i}+\varepsilon_{i j}+\xi_{i}
\end{aligned}
$$

ahol $M=$ migráció, , $i$ ” településrôl,$j$ ” településre. Mivel $D_{i}$ fix, azaz állandó hatásnak tekintjük a küldő települést (és annak tulajdonságait is), így csak a fogadó település változóit vizsgáljuk parametrikusan; azaz a település jellemzőit leíró faktorokat (f), a településtípust (type) és a népességet (pop). Mivel a kapcsolatháló némileg a közigazgatási határoknak megfelelően strukturált, ezért (SC) változó jelzi, hogy azonos megyében található-e a küldő és fogadó település (közigazgatási közelség).

Emellett vizsgáljuk a távolság (d) szerepét is a vándorlásban, így a települések közötti útidő, valamint annak négyzete is tagja az egyenletnek. Az interakciós tagok szintén szerepelnek az egyenletben; az iWiW-kapcsolatok egy felhasználóra jutó számának és a távolság $\left(d_{i j} * \frac{\operatorname{conn}_{i j}, 2013}{u s e r}\right)$, valamint az egy felhasználóra jutó kapcsolatszám és a távolság négyzetének $\left(d_{i j}^{2} * \frac{\operatorname{conn}_{i j, 2013}}{u s e r}\right)$ szorzatai. 
Alternatív modelleket is megvizsgálunk a robosztusság tesztelésére, a 2009-2013 évekbeli vándorlást hozzáadva is kiszámítjuk az egyenletet. A megelőző évek vándorlása emellett olyan további hatásokat is lefedhet, amikre nem tudtunk másképpen kontrollálni. Ilyen lehet például a két település között fennálló, azokat összekapcsoló adminisztratív, tömegközlekedési kapcsolat, esetleg kulturális hagyomány.

\section{Eredmények}

A letelepedés helyének vizsgálatára vonatkozó keresztmetszeti elemzésben 2014-re vonatkozóan 5 specifikációt vizsgálunk és mindegyikben fix hatást alkalmazunk a küldő településre (3. táblázat). Elsőként csak a távolság és a vándorlás összefüggését (1. oszlop) vizsgáljuk, másodikként az iWiW-kapcsolatok változóját vonjuk be a modellbe (2. oszlop), majd az interakciós tagokat (3. oszlop). A 4. oszlopban hozzáadjuk a megelőző 5 év vándorlását is a modellhez, majd ezzel együtt is megvizsgáljuk a távolság és az online kapcsolatok összefüggéseit (5. oszlop). Mind az 5 specifikációban szerepelnek a kontrollváltozók (a fogadó település népessége, típusa és jellemzői), amelyek az alapvető pull-faktorokat írják le. (A teljes regressziós kimenetet, a letelepedési hely kiválasztását lásd a Melléklet 2. táblázatában.)

3. táblázat

Regressziós modell, a letelepedés helyének kiválasztása, 2014

Regression model, choice of destination, 2014

\begin{tabular}{|c|c|c|c|c|c|}
\hline \multirow{3}{*}{ Változó } & \multicolumn{5}{|c|}{ Településpár közötti, adott irányú vándorlás } \\
\hline & 1. & 2. & 3. & 4. & 5. \\
\hline & \multicolumn{5}{|c|}{ specifikáció } \\
\hline \multirow{2}{*}{ iWiW-kapcsolatok aránya, 2013} & & $0,0151 * * *$ & $0,0167 * * *$ & $0,0151 * * *$ & $0,0167 * * *$ \\
\hline & & $(0,000138)$ & $(0,000242)$ & $(0,000139)$ & $(0,000244)$ \\
\hline \multirow{2}{*}{ Távolság } & $-0,0448 * * *$ & $-0,0408 * * *$ & $-0,0445^{* * *}$ & $-0,0402 * * *$ & $-0,0438^{* * *}$ \\
\hline & $(9,86 \mathrm{e}-05)$ & $(0,000111)$ & $(0,000116)$ & $(0,000113)$ & $(0,000118)$ \\
\hline \multirow{2}{*}{ Távolság2 } & $9,84 \mathrm{e}-05^{* * *}$ & $9,11 \mathrm{e}-05^{* * *}$ & $9,96 \mathrm{e}-05^{* * *}$ & $8,94 \mathrm{e}-05^{* * *}$ & $9,78 \mathrm{e}-05^{* * *}$ \\
\hline & $(3,01 \mathrm{e}-07)$ & $(3,40 \mathrm{e}-07)$ & $(3,58 \mathrm{e}-07)$ & $(3,45 \mathrm{e}-07)$ & $(3,62 \mathrm{e}-07)$ \\
\hline \multirow{2}{*}{$\begin{array}{l}\text { Adott céltelepülést választók, } \\
2013\end{array}$} & & & & $0,00430^{* * *}$ & $0,00326 * * *$ \\
\hline & & & & $(0,000141)$ & $(0,000141)$ \\
\hline \multirow{2}{*}{ Interakció1: iWiW * távolság } & & & $-0,00012^{* * *}$ & & $-0,00013^{* * *}$ \\
\hline & & & $(1,29 \mathrm{e}-05)$ & & $(1,31 \mathrm{e}-05)$ \\
\hline \multirow{2}{*}{ Interakció2: iWiW * távolság2 } & & & $3,77 \mathrm{e}-06^{* * *}$ & & $3,80 \mathrm{e}-06^{* * *}$ \\
\hline & & & $(5,71 \mathrm{e}-08)$ & & $(5,77 \mathrm{e}-08)$ \\
\hline \multicolumn{6}{|l|}{ Kontrollváltozók } \\
\hline Megelőző 5 év vándorlása & nem & nem & nem & igen & igen \\
\hline $\begin{array}{l}\text { Fogadó település típusa, } \\
\text { jellemzői és népessége }\end{array}$ & igen & igen & igen & igen & igen \\
\hline Közigazgatási közelség & igen & igen & igen & igen & igen \\
\hline Megfigyelések száma & 5911872 & 2065273 & 2065273 & 2065273 & 2065273 \\
\hline Csoportok száma & 3134 & 2569 & 2569 & 2569 & 2569 \\
\hline
\end{tabular}

Területi Statisztika, 2021, 61 (1): 26-47; DOI: 10.15196/TS610102 
Az iWiW-kapcsolatok együtthatója minden specifikációban pozitív és szignifikáns, azaz a közösségi hálón a céltelepüléssel (a többi lehetőségnél) sűrűbb kapcsolatháló népszerúbbé teszi az adott viszonylatot; ami megfelel a H2 hipotézisnek.

A 2013. évi, tehát a megelőző évi vándorlásról megállapíthatjuk, hogy olyan viszonylatokban gyakoribb a költözés, amelyek a korábbi években is népszerúek voltak. A távolság és négyzetének hatása a vártnak megfelelő, a távolság növekedésével csökkenő ütemben mérséklődik a vándorlás.

A távolság és az online kapcsolatok interakciójából az derül ki, hogy ahogy nő a kapcsolatok arányának és az útidônek a szorzata, úgy nő az adott céltelepülést választók aránya is; azonban az útidő négyzetének és az online kapcsolatok szorzatának növekedése már az arányuk csökkenésével jár. Tehát a távolság növekedésével, hogyha a kapcsolatok relatív sűrűsége nagy, mégis nagy valószínűsége lehet a letelepedésnek.

2. ábra

\section{A település kiválasztásának gyakorisága a távolság és az online kapcsolatok függvényében, 2013}

Heatmap of destination choice frequency, depending on the distance and online connections, 2013

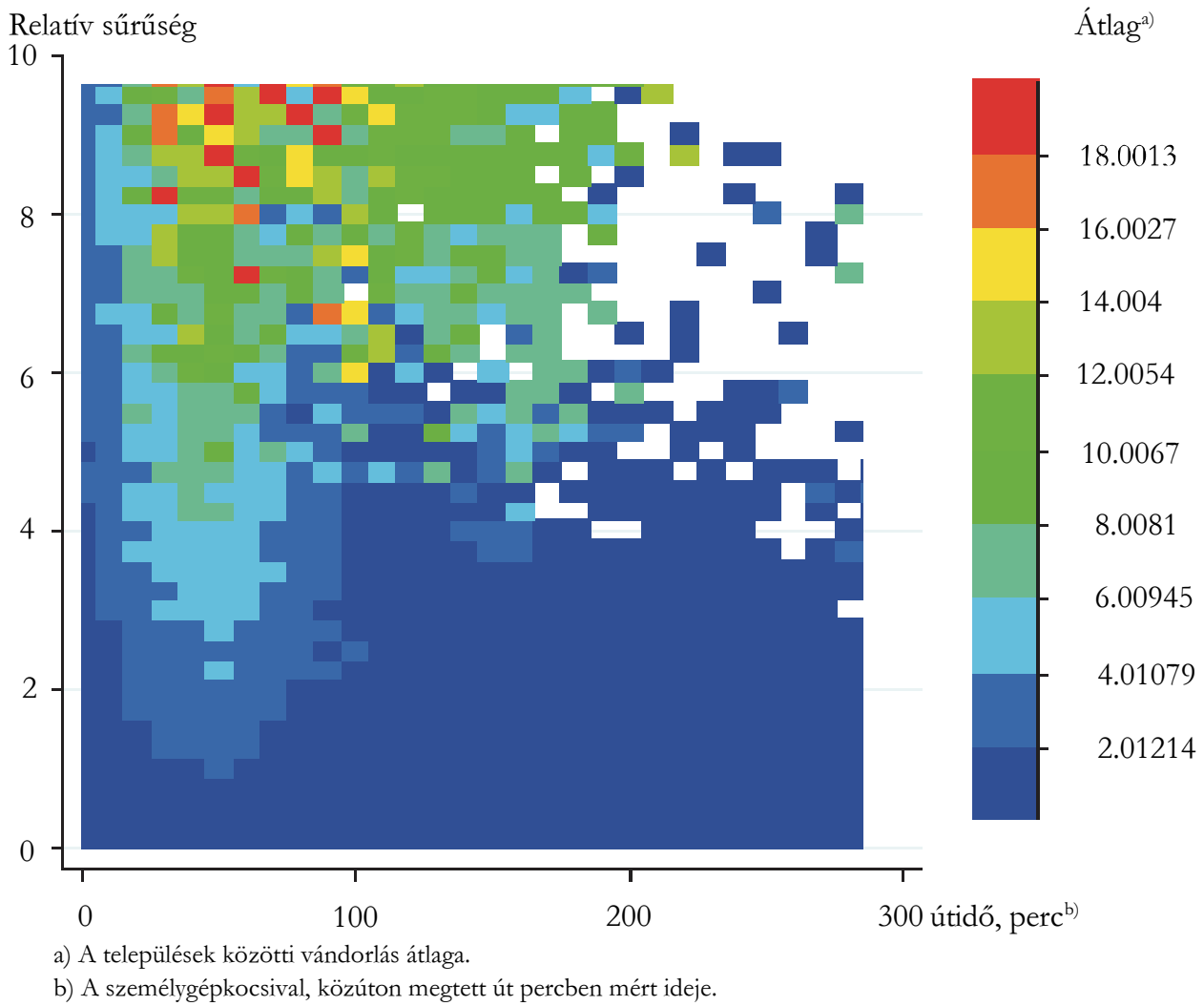

Területi Statisztika, 2021, 61(1): 26-47; DOI: 10.15196/TS610102 
A települések kiválasztásának gyakoriságát ábrázoló hőtérképen (2. ábra) a négyzeteket aszerint színeztük, hogy az online kapcsolatok relatív sűrűségének és az útidőnek adott tartományába tartozó települések között mekkora a vándorlás. Tehát egy négyzetbe az online kapcsolatok és a fizikai távolság szempontjából hasonló távolságra lévő települések kerültek, és aszerint színeztük őket a jobb oldali színskála alapján, hogy mekkora a közöttük lévő vándorlás átlaga. A vándorlások nagy része közepes távolságra irányul, és ezen belül a vándorlók előnyben részesítik azokat a településeket, amelyekkel több a kapcsolatuk; 20 és 200 perc közötti távolság esetén legnagyobb a vándorlások gyakoriságának átlaga, és ez növekszik a kapcsolatok relatív sủrűségének növekedésével. A kapcsolatháló szerepét a távolság szerint összehasonlítva megállapíthatjuk, hogy az kis és közepes távolság esetén a legnagyobb, valamint a közepes távolság esetén kiemelkedő.

A 2. ábra jobb felső tartományában a fehér négyzetek (nem megfigyelt értékek) gyakori megjelenése arra utal, hogy ritkán fordulnak elő olyan településpárok, melyek messze (több mint 200 perc autóútra) vannak egymástól, de mégis sok közöttük a kapcsolat, ami a kapcsolatok száma és a távolság közötti negatív kapcsolatra utal.

\section{Következtetések}

Kutatásunk a kapcsolathálók magyarországi belföldi vándorlásban játszott szerepével foglalkozik. A letelepedés helyének kiválasztását befolyásoló hatásokat vizsgáltuk, elsősorban az online kapcsolatok és a települések közötti távolság, valamint a kapcsolatháló kölcsönhatását.

Az eredmények alapján a települések kiválasztása pozitív és szignifikáns összefüggésben van az online közösségi hálón fenntartott kapcsolatok számával és irányával. Azt találtuk, hogy a különböző lehetőségek közül jellemzően olyan településre irányul a vándorlás, amellyel több online kapcsolatot tartanak fenn a vándorló eredeti lakóhelyén élő iWiW-felhasználók.

A vándorlás nagyrészt kis és közepes távolságra irányul, és ezen belül a vándorlók előnyben részesítik azokat a településeket, amelyekkel több a kapcsolatuk. A távolság bizonyos pontig való növekedésével, hogyha a kapcsolatok relatív sűrűsége nagy, mégis nagy lehet a valószínúsége a letelepedésnek, megfelelően az információs hipotézisnek és a rokonság vonzása hipotézisének (Schwartz 1973, Mulder-van der Meer 2009, Ermisch-Mulder 2019, Coombs 1978). A kapcsolatok és a távolság hatása korrelál, és mind a vándorlás, mind az emberi kapcsolatok (online kapcsolatok is) földrajzilag összpontosulnak (Lengyel et al. 2016).

Az eredményeink konzisztensek az információs hipotézissel és a rokonság vonzásának hipotézisével (Haug 2008), a hálózatok migrációra és annak távolságára gyakorolt hatása szempontjából. Számtalan korábbi kutatás ismertette a hálózatok befolyását a vándorlásra és a letelepedési hely kiválasztására (Deléchat 2001, Bauer et al. 2002, Nowotny-Pennerstorfer 2011), ennek bemutatására célunk a közösségi

Területi Statisztika, 2021, 61(1): 26-47; DOI: 10.15196/TS610102 
oldal kapcsolathálózatának kiaknázása volt. Azt feltételezzük, hogy az online kapcsolatháló hasonló előnyöket rejt, mint a nem közösségi oldalon fenntartott ismeretségi hálózat, vagy legalábbis előbbi megfelelő proxiként szolgálhat az utóbbihoz. Másik fó feltételezésünk, hogy az online kapcsolathálók valóban forrásai a vándorláshoz szükséges információ megszerzésének. Ezek a tényezők (ismeretek szerzése a tájékozódáshoz és munkalehetőségekkel kapcsolatban) egyéni szinten hatnak a vándorlással kapcsolatos döntésekre, azonban ezek kimenetelét mi közösségi szinten elemezzük. A korábbi kutatások között mind egyéni szintű elemzéseket (KobrinSpeare Jr 1983, Banerjee 1983, Deléchat 2001, Dawkins 2006), mind közösségi szintû elemzéseket is találunk (Johnston 1971, Carrington et al. 1996, NowotnyPennerstorfer 2011). 


\section{Melléklet}

A településjellemzők főkomponens-elemzésének korrelációs mátrixa, 2013 Principal Component Analysis correlation matrix of the settlement characteristics, 2013

\begin{tabular}{|c|c|c|c|c|c|c|c|}
\hline \multirow[b]{2}{*}{ Eredeti változók } & \multicolumn{6}{|c|}{ Faktorok: } & \multirow[b]{2}{*}{$\begin{array}{l}\text { Magya- } \\
\text { rázatlan } \\
\text { hányad }\end{array}$} \\
\hline & $\begin{array}{c}1 . \\
\text { Városi } \\
\text { közszol- } \\
\text { gáltatások }\end{array}$ & $\begin{array}{c}2 . \\
\text { Helyi } \\
\text { gazdaság }\end{array}$ & $\begin{array}{l}\text { 3. Szol- } \\
\text { gáltató } \\
\text { jelleg }\end{array}$ & $\begin{array}{c}4 . \\
\text { Alap } \\
\text { közszol- } \\
\text { gáltatások }\end{array}$ & $\begin{array}{c}5 . \\
\text { Munka- } \\
\text { erőpiac }\end{array}$ & $\begin{array}{l}6 . \\
\text { Ipari } \\
\text { jelleg }\end{array}$ & \\
\hline $\begin{array}{l}\text { Társas vállalkozások egy före jutó } \\
\text { száma (bt.+kft.) }\end{array}$ & 0,0641 & 0,2698 & 0,1455 & $-0,0764$ & 0,0484 & $-0,0480$ & 0,5981 \\
\hline $\begin{array}{l}\text { Egyéni vállalkozások egy före jutó } \\
\text { száma } \\
\text { Ipar nemzetgazdasági ágaiban a }\end{array}$ & $-0,0314$ & 0,6305 & $-0,0643$ & 0,0223 & $-0,2502$ & $-0,0417$ & 0,3303 \\
\hline $\begin{array}{l}\text { lpar nemzetgazdasági ágaiban a } \\
\text { társas vállalkozások száma } \\
\text { (összes társas vállalkozáson belül) }\end{array}$ & $-0,0063$ & $-0,0205$ & 0,0927 & $-0,0141$ & $-0,0086$ & 0,8144 & 0,04683 \\
\hline $\begin{array}{l}\text { Mezőgazdaság nemzetgazdasági } \\
\text { ágaiban a társas vállalkozások } \\
\text { száma (összes társas vállalkozá- } \\
\text { son belül) }\end{array}$ & 0,0191 & 0,0448 & $-0,6483$ & 0,0401 & 0,0162 & $-0,1684$ & 0,1834 \\
\hline $\begin{array}{l}\text { Szolgáltatások nemzetgazdasági } \\
\text { ágaiban a társas vállalkozások } \\
\text { száma (összes társas vállalkozá- } \\
\text { son belül) }\end{array}$ & $-0,0121$ & $-0,0236$ & 0,5105 & $-0,0246$ & $-0,0075$ & $-0,5192$ & 0,0546 \\
\hline $\begin{array}{l}\text { skedelmi boltok számának } \\
\text { tmusa }\end{array}$ & 0,3688 & $-0,0701$ & 0,1967 & 0,1494 & $-0,0280$ & 0,0428 & 0,1906 \\
\hline 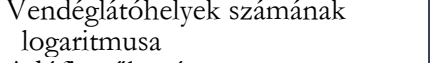 & 0,3566 & & 0,1986 & 0,1144 & & & \\
\hline Adófi & $-0,0181$ & 0,3751 & $-0,0792$ & 0,0138 & 0,3923 & $-0,0011$ & 0,2204 \\
\hline $\begin{array}{l}\text { at adóalap egy fơre jutó } \\
\text { n túli álláskeresők aránya }\end{array}$ & 0,0198 & 0,4653 & 0,0359 & $-0,0201$ & 0,1864 & 0,0136 & 0,228 \\
\hline & 0,0098 & 0,1282 & $-0,0407$ & $-0,0023$ & $-0,6506$ & & \\
\hline $\begin{array}{l}\text { egy fóre jutó száma } \\
\text { k számának }\end{array}$ & $-0,0333$ & 0,0573 & $-0,0824$ & 0,5362 & 0,0569 & $-0,0428$ & 0,4535 \\
\hline $\begin{array}{l}\log \\
\text { Bölc }\end{array}$ & 0,4177 & $-0,0273$ & $-0,1250$ & $-0,0730$ & 0,0204 & $-0,0491$ & 0,3461 \\
\hline $\begin{array}{l}\text { Sróhelyek egy fơre jutó } \\
\text { hhelvek egv főre jutó }\end{array}$ & 0,2628 & 0,1538 & $-0,0266$ & $-0,0218$ & $-0,1013$ & 0,0292 & 0,6569 \\
\hline & $-0,0198$ & 0,0458 & $-0,0223$ & 0,5333 & $-0,0498$ & $-0,0162$ & 0,4617 \\
\hline & 0,4430 & $-0,0021$ & $-0,0251$ & $-0,0483$ & $-0,0315$ & 0,0006 & 0,2212 \\
\hline lók számának & & & & & & & \\
\hline & & $-0,1592$ & & & & & \\
\hline Múze & 0,3250 & 0,0333 & $-0,0304$ & $-0,0119$ & $-0,0445$ & 0,0215 & 0,5763 \\
\hline $\begin{array}{l}\text { Ivóvízhálózatba kapcsolat lakások } \\
\text { aránya } \\
\text { Csatornahálózatba kapcsolt }\end{array}$ & $-0,0069$ & $-0,0204$ & $-0,0761$ & $-0,0107$ & 0,4958 & $-0,0053$ & 0,5992 \\
\hline laká & 0,0842 & 0,2755 & 0,1177 & $-0,0019$ & 0,1051 & 0,0949 & 0,5605 \\
\hline száma & 0,0432 & 0,1096 & 0,3317 & 0,0634 & 0,1340 & 0,1028 & 0,4989 \\
\hline
\end{tabular}

Megjegyzés: változónként a legerôsebb kapcsolatot szürke háttérrel emeltük ki.

Területi Statisztika, 2021, 61(1): 26-47; DOI: 10.15196/TS610102 
Teljes regressziós kimenet, a letelepedési hely kiválasztása, 2014 Complete regression output, choice of destination, 2014

\begin{tabular}{|c|c|c|c|c|c|}
\hline \multirow{3}{*}{ Változó } & \multicolumn{5}{|c|}{ Településpár közötti, adott irányú vándorlás } \\
\hline & 1. & 2. & 3. & 4. & 5. \\
\hline & \multicolumn{5}{|c|}{ specifikáció } \\
\hline \multirow{2}{*}{$\begin{array}{l}\text { iWiW-kapcsolatok egy főre jutó száma, } \\
2013\end{array}$} & & $0,0151^{* * *}$ & $0,0167 * * *$ & $0,0151^{* * *}$ & $0,0167 * * *$ \\
\hline & & $(0,000138)$ & $(0,000242)$ & $(0,000139)$ & $(0,000244)$ \\
\hline \multirow{2}{*}{ Távolság } & $-0,0448^{* * *}$ & $-0,0408^{* * *}$ & $-0,0445 * * *$ & $-0,0402 * * *$ & $-0,0438^{* * *}$ \\
\hline & $(9,86 \mathrm{e}-05)$ & $(0,000111)$ & $(0,000116)$ & $(0,000113)$ & $(0,000118)$ \\
\hline \multirow{2}{*}{ Távolság2 } & $9,84 \mathrm{e}-05^{* * *}$ & $9,11 \mathrm{e}-05^{* * *}$ & $9,96 \mathrm{e}-05^{* * *}$ & $8,94 \mathrm{e}-05^{* * *}$ & (9,78e-05*** \\
\hline & $(3,01 \mathrm{e}-07)$ & $(3,40 \mathrm{e}-07)$ & $(3,58 \mathrm{e}-07)$ & $(3,45 \mathrm{e}-07)$ & $(3,62 \mathrm{e}-07)$ \\
\hline \multirow[t]{2}{*}{ Interakció1: iwiw x távolság } & & & $\begin{array}{c}- \\
0,000119 * * *\end{array}$ & & $\frac{-}{0,000125^{* * *}}$ \\
\hline & & & $(1,29 \mathrm{e}-05)$ & & $(1,31 \mathrm{e}-05)$ \\
\hline \multirow{2}{*}{ Interakció2: iwiw x távolság2 } & & & $3,77 \mathrm{e}-06 * * *$ & & $3,80 \mathrm{e}-06^{* * *}$ \\
\hline & & & $(5,71 \mathrm{e}-08)$ & & $(5,77 \mathrm{e}-08)$ \\
\hline \multirow{2}{*}{ Adott céltelepülést választók, 2013} & & & & $0,00430 * * *$ & $0,00326^{* * *}$ \\
\hline & & & & $(0,000141)$ & $(0,000141)$ \\
\hline \multirow[t]{2}{*}{ Adott céltelepülést választók, 2012} & & & & $-0,00126^{* * *}$ & $* 0,000906 * * *$ \\
\hline & & & & $(0,000129)$ & $(0,000129)$ \\
\hline \multirow{2}{*}{ Adott céltelepülést választók, 2011} & & & & $-0,00209 * * *$ & $-4,98 \mathrm{e}-05$ \\
\hline & & & & $(0,000148)$ & $(0,000146)$ \\
\hline \multirow{2}{*}{ Adott céltelepülést választók, 2010} & & & & $-0,00242 * * *$ & $*-0,00346^{* * *}$ \\
\hline & & & & $(0,000113)$ & $(0,000114)$ \\
\hline \multirow{2}{*}{ Adott céltelepülést választók, 2009} & & & & $0,00237^{* * *}$ & $0,00188^{* * *}$ \\
\hline & & & & $(7,17 \mathrm{e}-05)$ & $(7,28 \mathrm{e}-05)$ \\
\hline \multirow{2}{*}{ Településtípus: főváros } & $-5,650^{* * *}$ & $-5,771 * * *$ & $-5,871 * * *$ & $-4,582 * * *$ & $-4,724 * * *$ \\
\hline & $(0,160)$ & $(0,167)$ & $(0,169)$ & $(0,168)$ & $(0,170)$ \\
\hline \multirow{2}{*}{ Településtípus: megyeszékhely } & $0,469 * * *$ & $0,404 * * *$ & $0,445^{* * *}$ & $0,398 * * *$ & $0,430 * * *$ \\
\hline & $(0,0142)$ & $(0,0147)$ & $(0,0146)$ & $(0,0147)$ & $(0,0147)$ \\
\hline \multirow{2}{*}{ Településtípus: város } & $0,307 * * *$ & $0,304 * * *$ & $0,336 * * *$ & $0,284 * * *$ & $0,314 * * *$ \\
\hline & $(0,00764)$ & $(0,00780)$ & $(0,00782)$ & $(0,00787)$ & $(0,00787)$ \\
\hline \multirow{2}{*}{ Fogadó település népesség } & $4,49 \mathrm{e}-06^{* * *}$ & $4,51 \mathrm{e}-06^{* * *}$ & $4,28 \mathrm{e}-06 * * *$ & $3,66 \mathrm{e}-06^{* * *}$ & * $3,48 \mathrm{e}-06^{* * *}$ \\
\hline & $(9,80 \mathrm{e}-08)$ & $(1,02 \mathrm{e}-07)$ & $(1,04 \mathrm{e}-07)$ & $(1,03 \mathrm{e}-07)$ & $(1,05 \mathrm{e}-07)$ \\
\hline \multirow{2}{*}{ Azonos megye? } & $1,087 * * *$ & $1,083^{* * *}$ & $0,927 * * *$ & $1,079 * * *$ & $0,928^{* * *}$ \\
\hline & $(0,00589)$ & $(0,00616)$ & $(0,00615)$ & $(0,00619)$ & $(0,00619)$ \\
\hline \multirow{2}{*}{ Városi közszolgáltatások } & $0,270^{* * *}$ & $0,247 * * *$ & $0,244 * * *$ & $0,248^{* * *}$ & $0,245^{* * *}$ \\
\hline & $(0,00125)$ & $(0,00131)$ & $(0,00131)$ & $(0,00132)$ & $(0,00132)$ \\
\hline
\end{tabular}




\begin{tabular}{|c|c|c|c|c|c|}
\hline \multirow{3}{*}{ Változó } & \multicolumn{5}{|c|}{ Településpár közötti, adott irányú vándorlás } \\
\hline & 1. & 2. & 3. & 4. & 5. \\
\hline & \multicolumn{5}{|c|}{ specifikáció } \\
\hline \multirow{2}{*}{ Helyi gazdaság } & $-0,137 * * *$ & $-0,119 * * *$ & $-0,113 * * *$ & $-0,126^{* * *}$ & $-0,119 * * *$ \\
\hline & $(0,00264)$ & $(0,00274)$ & $(0,00275)$ & $(0,00275)$ & $(0,00276)$ \\
\hline \multirow{2}{*}{ Alap közszolgáltatások } & $0,0490^{* * *}$ & $0,0277 * * *$ & $0,0388 * * *$ & $0,0297 * * *$ & $0,0401 * * *$ \\
\hline & $(0,00299)$ & $(0,00336)$ & $(0,00336)$ & $(0,00335)$ & $(0,00335)$ \\
\hline \multirow{2}{*}{ Munkaerőpiac } & $-0,0506^{* * *}$ & $-0,0493^{* * *}$ & $-0,0778^{* * *}$ & $-0,0482 * * *$ & $-0,0754 * * *$ \\
\hline & $(0,00282)$ & $(0,00293)$ & $(0,00292)$ & $(0,00293)$ & $(0,00293)$ \\
\hline \multirow{2}{*}{ Szolgáltató jelleg } & $0,292 * * *$ & $0,302^{* * *}$ & $0,265^{* * *}$ & $0,281 * * *$ & $0,251 * * *$ \\
\hline & $(0,00293)$ & $(0,00308)$ & $(0,00309)$ & $(0,00313)$ & $(0,00313)$ \\
\hline \multirow{2}{*}{ Ipari jelleg } & $0,0781 * * *$ & $0,0777 * * *$ & $0,0779 * * *$ & $0,0782^{* * *}$ & $0,0775^{* * *}$ \\
\hline & $(0,00396)$ & $(0,00414)$ & $(0,00415)$ & $(0,00415)$ & $(0,00415)$ \\
\hline Megfigyelések száma & 5911872 & 2065273 & 2065273 & 2065273 & 2065273 \\
\hline Csoportok száma & 3134 & 2569 & 2569 & 2569 & 2569 \\
\hline
\end{tabular}

Megjegyzések: Standard hibák zárójelben. *** $\mathrm{p}<0.01,{ }^{* *} \mathrm{p}<0.05,{ }^{*} \mathrm{p}<0.1$

Viszonyítási kategória településtípusok esetén: falu.

\section{Köszönetnyilvánítás}

A tanulmány elkészítését a Nemzeti Kutatási, Fejlesztési és Innovációs Hivatal az OTKA K129124 (Egyenlőtlenségek és egyensúlytalanságok a nagy hálózatokban) projekt keretében támogatta. A tanulmányhoz felhasznált belföldi vándorlás adatbázishoz a Központi Statisztikai Hivatal az MTA Közgazdaság- és Regionális Tudományi Kutatóközpont (KRTK) kutatószobában biztosított hozzáférést. Köszönettel tartozunk az MTA KRTK Adatbankjának.

\section{IRODALOM}

AlpeK, B. L.-Tésits, R.-HovÁNYI, G. (2018): Spatial inequalities of disadvantage accumulation and their impact on employability in Hungary Regional Statistics 8 (1): 96-119. https://doi.org/10.15196/RS080104

BÁLINT, L.-GÖDRI, I. (2015): Belföldi vándorlás. In: MONOSTORI, J.-ŐRI, P.-SPÉDER, Zs. (szerk.): Demográfiai portré pp. 171-186., KSH NKI, Budapest.

BÁlint, L.-CSÁNYI, Z.-FARKAS, M.-HLuCHÁNY, H.-KInCSES, Á. (2017): International migration and official migration statistics in Hungary Regional Statistics 7 (2): 101-123. https://doi.org/10.15196/RS070203

BAuer, T. K.-Epstein; G. S.-GANG, I. N. (2002): Herd effects or migration networks? The Location Choice of Mexican Immigrants in the US https://papers.ssrn.com/sol3/papers.cfm?abstract_id=333740. (letöltve: 2020. június)

Területi Statisztika, 2021, 61(1): 26-47; DOI: 10.15196/TS610102 
BAYER, P.- Ross; S. L.-TOPA, G. (2008): Place of work and place of residence: Informal hiring networks and labor market outcomes Journal of Political Economy 116 (6): 1150-1196. https://doi.org/10.1086/595975

BANERJEE, B. (1983): Social networks in the migration process: Empirical evidence on chain migration in India The Journal of Developing Areas 17 (2): 185-196.

Blumberg, L.-Bell, R. R. (1958): Urban migration and kinship ties Social Problems 6 (4): 328-333. https://doi.org/10.2307/799366

Blumenstock, J.-CHI, G.-TAN, X. (2019): Migration and the value of social networks CEPR Discussion Paper No. DP13611 https://ssrn.com/abstract=3360078. (letöltve: 2020. június)

BOZA, I.-ILYÉs, V. (2018): A korábbi munkatársak bérekre gyakorolt hatása Közgazdasági Szemle 65 (7-8): 726-767. https://doi.org/10.18414/KSZ.2018.7-8.726

BÜChel, K.-Puga, D.-Viladecans-Marsal, E.-VON Ehrlich, M. (2020): Calling from the outside: The role of networks in residential mobility Journal of Urban Economics 119: 103277. https://doi.org/10.1016/j.jue.2020.103277

Carrington, W. J.-Detragiache, E.-Vishwanath, T. (1996): Migration with endogenous moving costs The American Economic Review 86 (4): 909-930.

CHEN, W.-CHOI, A. S. K. (2011): Internet and social support among Chinese migrants in Singapore New Media \& Society 13 (7): 1067-1084. https://doi.org/10.1177/1461444810396311

ChOldin, H. M. (1973): Kinship networks in the migration process International Migration Review 7 (2): 163-176. https://doi.org/10.2307/3002426

Coombs, G. (1978): Opportunities, information networks and the migration-distance relationship Social Networks 1 (79): 257-276.

CSERES-Gergely, Zs. (2005): County to county migration and labour market conditions in Hungary between 1994 and 2002 Budapest Working Papers on the Labour Market, Institute of Economics, Hungarian Academy of Sciences, Budapest.

DAVAnZO, J. (1981): Repeat migration, information costs, and location-specific capital Population and Environment 4 (1): 45-73. https:/ / doi.org/10.1007/BF01362575

DAWKINS, C. J. (2006): Are social networks the ties that bind families to neighborhoods? Housing Studies 21 (6): 867-881. https://doi.org/10.1080/02673030600917776

DEKKER, R.-ENGBERSEN, G. (2014): How social media transform migrant networks and facilitate migration Global Networks 14 (4): 401-418. https://doi.org/10.1111/glob.12040

DeLÉCHAT, C. (2001): International migration dynamics: The role of experience and social networks Labour 15 (3): 457-486. https://doi.org/10.1111/1467-9914.00173

Dorigo, G.-ToBler, W. (1983): Push-pull migration laws Annals of the Association of American Geographers 73 (1): 1-17. https://doi.org/10.1111/j.1467-8306.1983.tb01392.x

ELLISON, N. B.-BOYD, D. M. (2013): Sociality through social network sites. In: The Oxford Handbook of Internet Studies pp. 151-172., Oxford University Press, Oxford. https://doi.org/10.1093/oxfordhb/9780199589074.013.0008

ERMisCH, J.-MulDER, H. C. (2019): Migration versus immobility, and ties to parents European Journal of Population 35: 587-608. https://doi.org/10.1007/s10680-018-9494-0

Területi Statisztika, 2021, 61(1): 26-47; DOI: 10.15196/TS610102 
FAZEKAS, K. (2002): Regional disparities in unemployment in Central and Eastern Europe: The case of Hungary. In: Labor, employment, and social policies in the EU enlargement process pp. 176-196., World Bank, Washington, DC.

GLITZ, A.-VEJLIN, R. (2018): Learning through coworker referrals IZA DP No. 12270 IZA Institute of Labor Economics, Bonn.

HAJDU, M.-KÖLLŐ, J.-TÓTH, I. J. (2018): Manifest shortage - Vacancies and idle capacities. In: The Hungarian Labour Market 2017 MTA KRTK, Budapest.

HAMPTON, K.-Wellman, B. (2001): Long distance community in the network society: Contact and support beyond Netville American Behavioral Scientist 45 (3): 476-495. https://doi.org/10.1177/00027640121957303

HAUG, S. (2008): Migration networks and migration decision-making Journal of Ethnic and Migration Studies 34 (4): 585-605. https://doi.org/10.1080/13691830801961605

HeNSVIK, L.-NORDSTRÖM SKANS, O. (2016): Social networks, employee selection, and labor market outcomes Journal of Labor Economics 34 (4): 825-867. https://doi.org/10.1086/686253

Hiller, H. H.-Franz, T. M. (2004): New ties, old ties and lost ties: The use of the Internet in diaspora New Media \& Society 6 (6): 731-752. https://doi.org/10.1177/146144804044327

JOHNSTON, R. J. (1971): Resistance to migration and the mover/stayer dichotomy: Aspects of kinship and population stability in an english rural area Geografiska Annaler: Series B, Human Geography 53 (1): 16-27. https://doi.org/10.1080/04353684.1971.11879352

KERTESI, G. (1997): A gazdasági ösztönzők hatása a népesség földrajzi mobilitására 1990 és 1994 között Esély 2: 3-32.

Kim, J. H.-PAgliara, F.-Preston, J. (2005): The intention to move and residential location choice behaviour Urban Studies 42 (9): 1621-1636. https://doi.org/10.1080/00420980500185611

KINCSES, Á.-BÁLINT, L. (2016a): Vándorlási települési hálózatok a Kárpát-medencében Terïleti Statisqtika 56 (1): 89-108.

KINCSES, Á.-BÁLINT, L. (2016b): Migration settlement networks in the Carpathian Basin, 2001-2011 Regional Statistics 6 (2): 95-113. https://doi.org/10.15196/RS06205

KOBRIN, F. E.-SPEARE JR., A. (1983): Out-migration and ethnic communities International Migration Review 17 (3): 425-444. https://doi.org/10.1177/019791838301700303

KóTI, T. (2018): Spatial differences regarding the chance to leave supported public employment in Hungary's rural periphery Regional Statistics 8 (2): 109-134. https://doi.org/10.15196/RS080210

KRAMARZ, F.-NORDSTRÖM SKANS, O. (2014): When strong ties are strong: Networks and youth labour market entry The Review of Economic Studies 81 (3): 1164-1200. https://doi.org/10.1093/restud/rdt049.

LASCHEVER, R. (2013): The doughboys network: Social interactions and the employment of world War I veterans SSRN Scholarly Paper ID 1205543. Social Science Research Network, Rochester, NY. https:/ / papers.ssrn.com/abstract=1205543. (letöltve: 2020. június)

LENGYEL, B.-VARGA, A.-JAKOBI, Á.-KERTÉSZ, J.-SÁGVÁRI, B. (2016): Az iWiW földrajza Területi Statisztika 56 (1): 30-45.

Területi Statisztika, 2021, 61(1): 26-47; DOI: 10.15196/TS610102 
LITVAK, E. (1960): Geographic mobility and extended family cohesion American Sociological Review 25 (3): 385-394.

Massey, D. S.-Arango, J.-Hugo, G.-Kouaouci, A.-Pellegrino, A.-Taylor, J. E. (1993): Theories of international migration: A review and appraisal Population and Development Review 19 (3): 431-466. https://doi.org/10.2307/2938462

Mulder, C. H.-VAN Der MeER, M. J. (2009): Geographical distances and support from family members Population, Space and Place 15 (4): 381-399. https://doi.org/10.1002/psp.557

Nechyba, T. J.-Strauss, R. P. (1998): Community choice and local public services: A discrete choice approach Regional Science and Urban Economics 28 (1): 51-73. https://doi.org/10.1016/S0166-0462(97)00013-6

NÉMETH, B.-LŐRINC, L. (2019): Hálózati hatások a belföldi migrációban Szociológiai Szemle 29. (1): 117-145.

NOWOTNY, K.-PENNERSTORFER, D. (2011): Ethnic networks and the location choice of migrants in Europe Working Papers in Economics, Fachbereich Sozial- und Wirtschaftswissenschaften, Universität Salzburg, Salzburg.

NovotNÝ, L.-PREGI, L. (2018): Visualization of migration using spatial interpolation method in Hungary and Slovakia Regional Statistics 8 (2): 184-188. https://doi.org/10.15196/RS080206

RAVEnsteIN, E. G. (1889): The laws of migration Journal of the Royal Statistical Society 52 (2): 241-305.

Ritchey, P. N. (1976): Explanations of migration Annual Review of Sociolology (2): 363-404.

SÁGVÁRI, B. (2019): Tér és társadalom Big Data szemüvegen keresztül Területi Statisztika 59 (1): 27-48. https://doi.org/10.15196/TS590102

SAYgin, P.-Weber, A.-WEynAndT, M. (2014): Coworkers, networks, and job search outcomes ILR Review https://doi.org/10.1177/0019793919881988 (Online first)

SCHWARTZ, A. (1973): Interpreting the effect of distance on migration Journal of Political Economy 81 (5): 1153-1169.

SCHWARZWELLER, H. K. (1964): Parental family ties and social integration of rural to urban migrants Journal of Marriage and the Family 26 (4): 410-416. https://doi.org/10.2307/349345

SJAASTAD, L. A. (1962): The costs and returns of human migration Journal of Political Economy 70 (5. Part 2): 80-93.

ŠPaČKOvÁ, P.-DvořákOvÁ, N.-TobrmanovÁ, M. (2016): Residential satisfaction and intention to move: The case of Prague's new buburbanites Geografiska Annaler: Series B, Human Geography 98 (4): 331-348. https://doi.org/10.1111/geob.12108

SPEARE, A. (1974): Residential satisfaction as an intervening variable in residential mobility Demography 11 (2): 173-188. https://doi.org/10.2307/2060556

STOKEnBERGA, A. (2019): How family networks drive residential location choices: Evidence from a stated preference field experiment in Bogotá, Colombia Urban Studies 56 (2): 368-384. https://doi.org/10.1177/0042098017711396

SZABÓ, T. (2019): Public service as an indicator of competitiveness Regional Statistics 9 (2): 213-234. https://doi.org/10.15196/RS090211 
TAgAi, G.-Bernard, J.-Šimon, M.-Koós, B. (2018): Two faces of peripherality: labour markets, poverty, and population dynamics in Hungary and Czechia Regional Statistics 8 (2): 19-45. https://doi.org/10.15196/RS080204

TÓTH, I. J.-NYÍRŐ, Zs. (2018): Labour shortage" in the Hungarian public discourse. In: The Hungarian Labour Market 2017 pp. 57-62., Institute of Economics, Centre for Economic and Regional Studies, Hungarian Academy of Sciences, Budapest.

Wellman, B.-Wortley, S. (1990): Different strokes from different folks: Community ties and social support American Journal of Sociology 96 (3): 558-588.

YE, J. (2006): Traditional and online support networks in the cross-cultural adaptation of Chinese international students in the United States Journal of Computer-Mediated Communication 11 (3): 863-876.

https://doi.org/10.1111/j.1083-6101.2006.00039.x

Területi Statisztika, 2021, 61(1): 26-47; DOI: 10.15196/TS610102 